\title{
ETHICAL ASPECTS OF COMMUNICATION WITH CLIENTS IN PHONE BANKING
}

\author{
Monika Szewczyk \\ Faculty of Economics and Sociology \\ University of Łódź
}

\begin{abstract}
The current state of development of technology allows communication through more and more new channels. The internet and mobile phones have become the main way to communicate. Banks and other financial institutions use these new forms of communication to maintain a constant relation with their clients. Most of these new forms not only support the activity of banks, but also facilitate use of the bank's products and services by the client. One of the most popular forms of communication with clients is by phone. At the same time, the developments in the concept of corporate social responsibility are observed and determine ethical rules for business. The rules examined in this paper relate to consumer issues, and the paper discusses some ethical aspects, such as relations with clients, fair and transparent marketing policy, market education, reliable information about the products and services and their impact on the health and safety of the customers. The aim of this study is to examine whether phone banking is perceived by clients as an ethical method of communication. The paper analyzes the ethical aspects of phone banking and also presents empirical findings on the basis of research conducted among the clients.
\end{abstract}

Keywords: phone banking, financial services, business ethics, corporate social responsibility.

JEL Class: G20, M14. 


\section{INTRODUCTION}

The spread of high-tech solutions in all spheres of economic life has accordingly brought about changes in the financial sector. Other factors influencing these changes include the growing consumer awareness of banking products and the growing demand for banking services. These aspects have led to new developments in banking and the transformation of bank strategies orientated on a product to ones focused on the client. At the same time, the technology has led to the creation of electronic banking (e-banking). This solution has many advantages, including the freedom of place and time of using banking services, self-service, access to wide range of products, as well as the choice of distribution channel. E-banking uses modern channels of distribution such as home banking, phone banking, i-banking (via the Internet), mobile banking, TV-banking, as well as modern cash machines. It is also worth noting that the desire to attract a new group of clients, i.e. young people willing to use modern products and technologies, has brought about the creation of a new type of banks called Mcbanks [Pluskota 2003: 35]. The branches of this new banking network occupy a small area and employ only a few employees, called the front office. They include installed ATMs, which are multifunctional cash machines which facilitate payments and withdrawals, checking one's account balance, changing passwords, or printing bank statements. Call centres are an integral feature of Mcbanking and its role is to replace the traditional way of communication with consultants at the bank branch [Pluskota 2003: 35]. Therefore, thanks to the new developments in technology phone banking is used not only as a new channel of distribution and communications with clients, but also is a response to the needs of a new group of customers. Comparing to other options such as the Internet, phone banking offers great opportunities for services such as banking to reach critical mass [Brown et al. 2003: 392]. The aim of the study is to examine ethical aspects of communication by phone with the clients of the banks. The paper also presents empirical findings on the basis of the research conducted among the clients. The purpose of the research was to evaluate phone conversations with bank's clients in terms of ethical aspects, to identify the purpose of communication with clients and also verify the willingness and the reasons of concluding or not concluding the agreements by phone. The main aim of this paper is to study whether phone banking is perceived by clients as an ethical method of communication. 


\section{PHONE BANKING AS A FORM OF CUSTOMER SERVICE}

Phone banking is a service which uses mobile phone to mutually communicate with a client. Two types of phone banking can be distinguished [KNF 2010: 38]:

1) phone banking, using landline phones,

2) mobile banking, using mobile phones and other mobile devices.

New channels of communication also undergo modifications and transformations and thus new forms are being constantly developed. Thus nowadays there are two basic forms of phone banking [Pluskota 2003: 46]:

1) human-human;

2) human-machine.

In a human-human relation, the communication is managed between the client and the bank consultant working in a call centre. Today call centres have become a popular service offered by banks. They are a phone customer service operated by the consultant of the bank with the use of two-way voice communication, allowing banking transactions via landline [KNF 2010: 39). The range of banking services through the use of call centres is varied and depends on the offer of individual banks. In the case of human-machine interactions, the IVR (Interactive Voice Response) system is used. This is an automatic telephone service bank with the use of unilateral voice communication. It recognizes people's voice or a message on the basis of a sequence of characters on the phone keyboard selected by the customer. Then it exchanges the text file for a voice that passes the information to the client. The range of banking services offered via IVR is limited in comparison to a call centre, and it is not possible to service non-standard operations in this system. Most phone banking systems combine both of these types of communication. This helps to manage phone calls and information about the clients and facilitates the activities involved in phone banking [Zalewska-Bochenko 2013: 298].

The aim of introducing phone banking as new form of communication is to change the trend toward attachment to a bank and to convince clients to open accounts in other banks, as well as increase the loyalty of current clients. Another aim is also to reduce the number of operations in traditional bank branches, which enable active sales. Phone banking could help reduce the operating costs of financial institutions and also banks are able to create a strategic competitive advantage if financial services are delivered over mobile phones [Talukder et al. 2014: 84]. Phone banking also has a lot of advantages for clients. There are no costs of equipment - it is enough to have tone mobile device.

The dynamic development of phone banking took place in the 1960s and its popularity increased particularly rapidly in the United States [Polasik 2008: 36]. Initially, only simple transactions were carried out and access to money was 
passive. The growing dissemination and sophistication of phones (especially mobile phones) and the increased security of such transactions increased the number of services offered and made us via telephone. Currently banks offer a very wide range of services via phone banking. These include [Pluskota 2003: 46]:

1) checking account balances;

2) transferring bank statements;

3) card blocking;

4) carrying out money transfers to accounts at the bank or other banks;

5) opening and closing time deposits;

6) creating or changing standing orders and direct debits;

7) cheque ordering or restriction;

8) the possibility to obtain information about the bank's offers.

Most of the above mentioned services are provided due to contact initiated by the client. But it is worth noting that nowadays ever more phone calls are initiated by banks. Apart from the above mentioned areas of services that can be conducted by phone banking, there are other reasons for communication with the client. As the finance sector is oriented toward a customer, more and more phone calls are being made with the aim to check the satisfaction of a client. Other reasons include: providing customer education, suggesting new products and services, offering additional financial assets such as loans and credits, and even offering insurance.

At the same time services that have been so far were conducted by phone can now be conducted via the Internet. The Internet has become ever more popular and more available and it has taken over most of tasks that were earlier served by phones. It is worth adding that cell phone banking may be considered as an extension of Internet banking [Brown et al. 2003: 383]. The Internet banking can be also seen as an potential threat to phone banking [Calisir et al. 2008: 220]. This channel of distribution is comfortable for clients because they are able to read most items and to do so without any mediators.

\section{ETHICAL ASPECTS OF PHONE BANKING}

Ethics in the activity of banks is of utmost importance, because they are an institution of public trust. Banks operate as economic players, but also fulfil non-market functions. First of all, banks are of a commercial character, which means that they are responsible for realization of economic functions to provide for the welfare of the owners. And secondly, banks also have a social character, which means its social influence should be provided by granting the society access to welfare and creating desired social relations [Korenik 2009: 19]. The social 
responsibility of financial institutions and banks is related to providing clients with access to their financial assets and confidential information about products or personal details. Banks are a crucial element of the protection of personal property, and the security of deposits is a significant factor in maintaining social and economic stability. At the same time clients put their trust in the credibility of banks. They believe that banks offer them services of the highest level of quality. The reason for this is that financial products are complicated and clients need to choose them with the help of the bank's consultants. That also requires ethical behaviour on the part of a bank's employees, and actions leading to clients' education and awareness [Milic-Czerniak 2012: 44].

As mentioned above, the banking business is oriented toward clients and their needs and expectations. Thus responsibility towards clients is a decisive factor in the development of a bank. Corporate social responsibility is a concept based on combining business goals with social expectations. At present, this kind of approach seems to be crucial for running any kind of business and it is also desired by the society. Corporate social responsibility (CSR) means that companies take their own initiatives and, independently of legislation and legislative oversight, take actions to help society and the environment (European Commission). There are seven core subjects that form the basis for a holistic approach to CSR. They correspond to areas such as: organizational governance, human rights, labour practices, the environment, fair operating practices, consumer issues, community involvement and development [ISO 2014: 9].

In terms of the aims of this paper, the most important factor of responsible and ethical behaviour is related to consumer issues. This area aspect encompasses aspects such as relations with customers, fair and transparent marketing policies, consumer education, reliable information about the products and services available and their impact on the health and safety of the customers, and responsible consumption or facilities for customers.

There are many factors associated with banks' activities that affect the consumer and his or her trust in the bank. These factors include: regulatory compliance, guarantee schemes, the preservation of bank secrecy, confidence in concluding agreements, the application of good practices and ethical codes, transparent and reliable financial statements and reports, and reliable information and advertising. Transparency is especially important in the banking sector. Customers entrust their financial resources to banks and they expect transparency and understandable information from the financial institutions. Reliable reports help customers to make conscious decisions. Thus not only is reliable information and communication with clients very important, but also advertising and other PR activities [Łukasiewicz-Kamińska 2011: 44].

In phone banking these aspects become even more significant because during the phone call the client does not see any paper document or offer. It is important 
that the employee of the bank gives reliable and transparent information and presents the full offer of the product or service, together with all of the conditions of its use. Moreover, when the product or service is complicated or the client simply doesn't understand some of the information, the bank consultant should be prepared to explain and elucidate in order to educate the client in this area. Hence another aspect is the way of communication. A good and clear way of communication is demanded not only by clients but also by general ethical rules, which require bank consultants to communicate in a polite and convenient way. Clients do not accept having to deal with bothersome consultants. One of the really significant aspects is also, understandably, safety and confidentiality, especially with respect to clients' personal data and preferences.

\section{METHODOLOGY OF THE RESEARCH}

The main aim of this study was to examine whether phone banking is perceived by clients as an ethical method of communication. The research was conducted among potential bank customers by sending a questionnaire to them via the Internet. The examined group of potential customers was chosen among friends, family, co-workers, and students. The respondents, as potential bank clients, were chosen among people in different ages and from different social groups. Replies were obtained from a group of 44 people. Women accounted for $68.18 \%$ of the group of respondents. More than half of respondents $(54.55 \%)$ were aged 16-24 years, less than half (43.18\%) were between 25 and 40 years old, and only $2.27 \%$ were older than 41 years. The professional profile of the respondents was the distributed as follows: $55 \%$ of the respondents were students, $36 \%$ were employees, $7 \%$ were persons running their own company, while only $2 \%$ were unemployed. Among all the respondents, $77 \%$ were persons with higher education, and the other $23 \%$ were people with secondary education.

The aim of the first part of the survey was to check whether the surveyed consumers use banks services and if the bank contacted them through phone banking. If the answers in the first part of the survey were affirmative, the respondents moved to the second part, which checked their opinion about the ethical aspects of phone banking. Respondents were asked about issues such as the goals of the phone calls from consultants, the way of communication with them, their preferred form of the contact with the bank, and also if they concluded any agreements by phone. In the case of a negative response in the first part of the survey (i.e. no contact through phone banking), respondents had only to fill in some relevant personal data. 


\section{EMPIRICAL FINDINGS}

Only three respondents (7\%) replied that they do not use banking services and $75 \%$ of respondents declared that their bank had contacted with them by phone. The first part of the survey thus eliminated from the study $25 \%$ of respondents. Further questions about the ethical aspects of communication through phone banking thus involved $75 \%$ of the total number of respondents, i.e. a total of 33 persons.

The second part of the survey aimed at obtaining the opinion of the respondents with respect to their perceptions of the phone contact by banks with them, and the ethical aspects of this form of communication. In the question number 3 they were asked how they evaluate the form of phone contact by the bank. Almost half of respondents replied that this form suits them, but that they would prefer to initiate the contact with bank depending on their current needs. And $21 \%$ of those surveyed confirmed that phone form of communication with bank does not suit them and they consider that bank consultants just take their time. Another $18 \%$ of respondents said that, that kind of contact does not suit them because they do not like talk about financial issues by phone. Only 9\% (3 people) declared that this form suits them and that, thanks to phone contact they do not have to waste their time going to the bank. One respondent marked the option "other" and explained: „This form suits me in the context of the information but usually to complete the transaction (the launch of new services, etc.) I go to the bank personally or ask them to send me information via an e-mail."

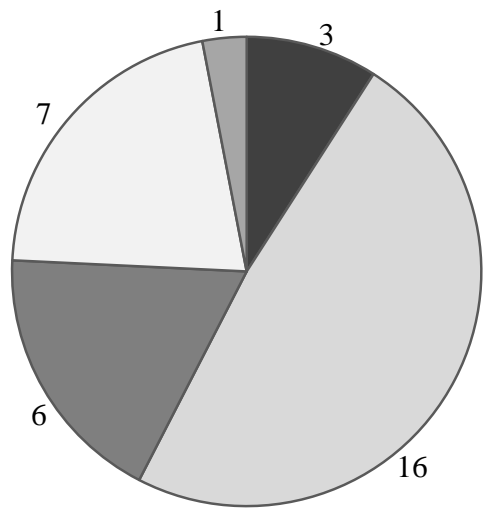

\section{Question 3}

This form suits me, I do not waste my time to get to the bank.

$\square$ This form suits me but I would prefer to initiate contact with the bank depending on my current needs.

$\square$ This form does not suit me, I do not like to talk about financial issues by phone.

$\square$ This form does not suit me, consultants of the bank just take my time.

口other

Figure 1. Evaluation of the form of phone contact by a bank

Source: Own study based on the research. 
In the next question, the respondents were asked about the goals of the phone calls with banks consultants. In this question those surveyed were able to mark more than one answer. Forty-two percent of the respondents reported that the phone calls included offering new services or products, and other $42 \%$ reported that they included offering a loan or credit, while $11 \%$ reported that the goal of the phone calls was to obtain an opinion in relation to their previous cooperation with the bank, and $6 \%$ reported that the goal of the phone calls was to provide the client with education in terms of using banking services. It is worth noting that the objective of most phone calls was to offer or sell new products or services.

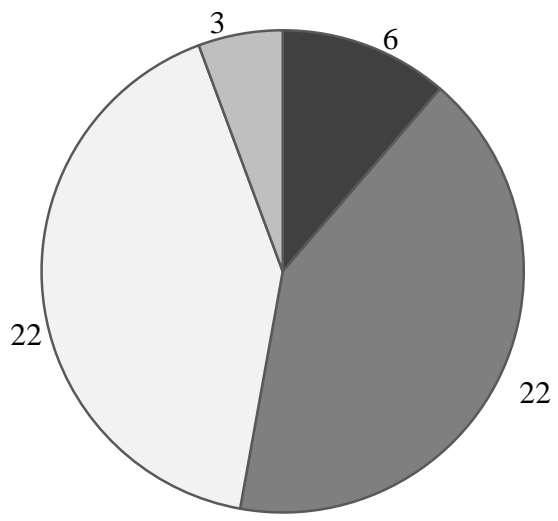

\author{
Question 4 \\ gaining opinion in relation to the \\ previous cooperation with the bank \\ $\square$ offering new services or products \\ 口offering a loan or credit \\ Qeducation in terms of using banking \\ services
}

Figure 2. The goals of initiating phone contact by the bank

Source: Own study based on the research.

Questions four and five were aimed at determining whether the phone conversations were conducted in a polite or in a bothersome way. It was explained that a „bothersome way” meant that despite the lack of desire on the part of a respondent to continue the conversation consultant was maintaining it at all costs. All of the respondents confirmed that the phone calls with the bank were conducted in a polite way. But a majority of the respondents (55\%) also found the conversations bothersome (see fig. 3).

In the next question the respondents were asked if they concluded any agreement for services or banking products by phone (see fig. 4). It should be noted here that most of respondents (more than 90\%) did not conclude any agreement by phone. Hence these respondents were asked, in question nine, about the reason of not concluding any agreement by phone. A significant part of them (73\%) admitted that they did not do that because they think that it is dangerous and they prefer to read an agreement on their own before signing it, although $10 \%$ 
remarked that they did not have an opportunity to do that and the remaining $17 \%$ checked the „other" option and explained that: „I didn't have such a need”, „I was not interested”, „I didn't need to use any new product”, „It was a poor offer” and „I'm visualizer and I won't remember the details discussing them only in a phone conversation." Those who confirmed that did conclude an agreement by phone, which were only three persons, were asked about the transparency and comprehensibility of the terms of the agreement terms. Only one person from these three admitted that the terms of the agreement were not understandable and transparent.

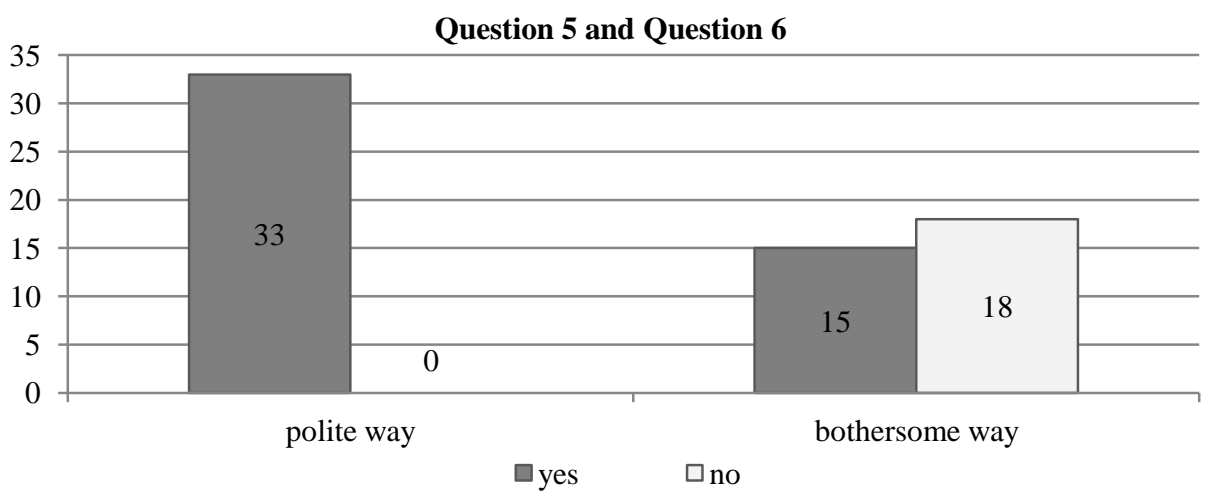

Figure 3. Evaluation of the way of communicating during the phone calls

Source: Own study based on the research.

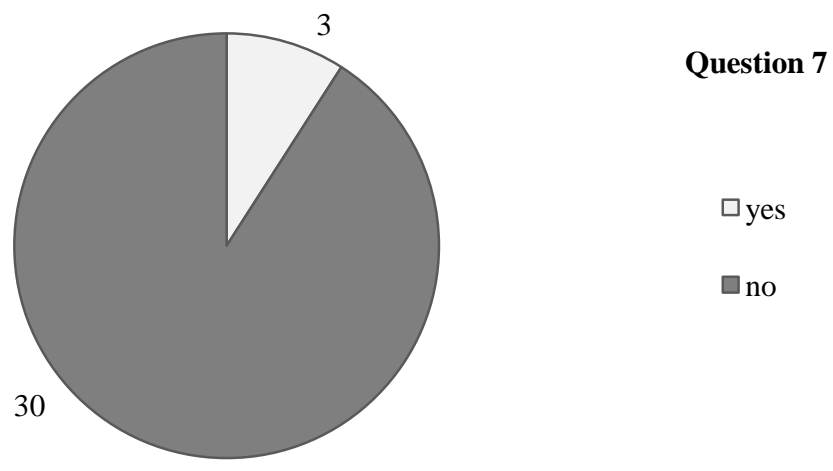

Figure 4. The number of people who concluded an agreement for services or products through phone banking

Source: Own study based on the research. 


\section{Question 8}

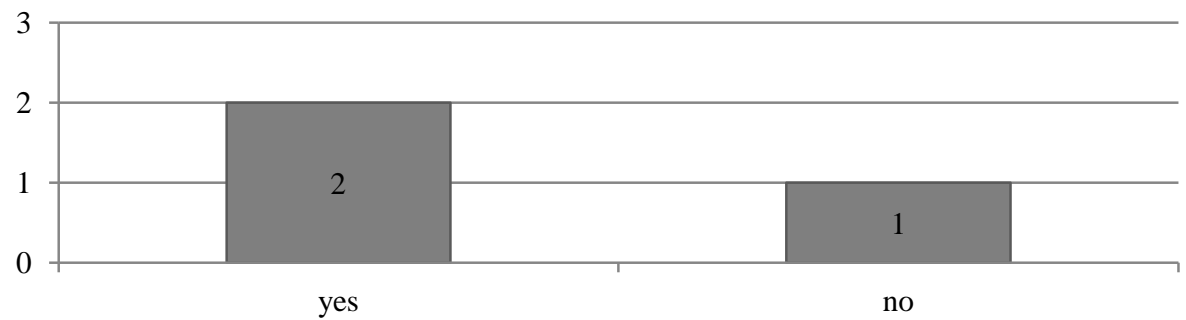

Figure 5. The number of people who perceived terms of the agreement as transparent and understandable

Source: Own study based on the research.

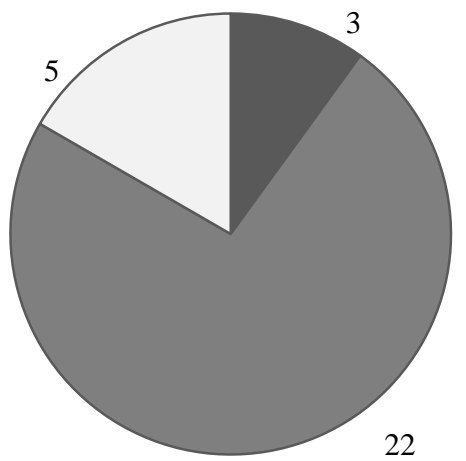

\section{Question 9}

I did not have such an opportunity.

$\square$ I think it is dangerous, before concluding the contract I like to read it.

$\square$ other

Figure 6 . The reasons of not concluding an agreement by phone

Source: Own study based on the research.

The last question was aimed at finding out what kind of contact with a representative of the bank is preferred by the respondents. Here $64 \%$ of those surveyed stated that they prefer direct meeting in bank branch, $18 \%$ prefer contact via Internet, and only 9\% (3 people) stated that they prefer phone banking as a form of communication with the bank. Also 9\% (3 persons) marked „other”, and explained that they prefer: ,a direct meeting in a bank branch", „contact via the Internet, unless in a special case the phone call is initiated by me" and „combining phone communication and subsequent continuation during a visit in the bank branch works for me the best". 


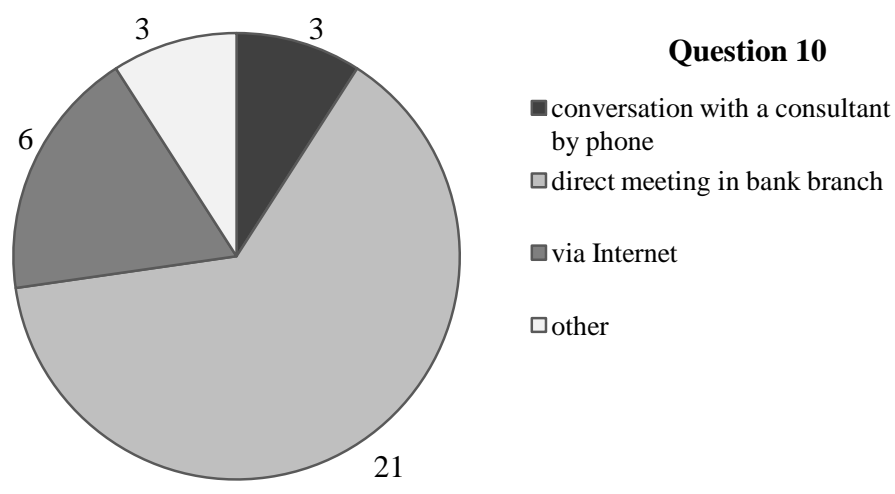

Figure 7. Preferred form of communication with the bank

Source: Own study based on the research.

\section{CONCLUSIONS}

The paper has described phone banking as a part of e-banking and a new channel of communication with a bank. It has shown that the most popular form of phone banking is a call centre, and that a wide range of services can be offered by phone banking. It was also noted that actually most of phone calls are initiated by bank consultants. Banks are institutions vested with a public trust, hence the ethical aspects of its activity are crucially important. This paper has concentrated on consumer issues. The research conducted among customers showed that generally customers prefer direct contact with the bank consultant than a communication via phone banking. It was also noted that customers prefer to initiate contact with the bank when they need it, rather than have the banks call them. Customers do not like conclude agreements by phone because they think that it can be a dangerous practice - they prefer to read the agreement before signing it. It seems that customers do not trust that the bank consultant will pass all the information to them by phone. This can be a result of a conservative approach by people as well as their ingrained habits with the traditional way of communicating with the bank.

\section{BIBLIOGRAPHY}

Brown I., Cajee Z., Davies D., Stroebel S., 2003, Cell phone banking: predictors of adoption in South Africa - an exploratory study, International Journal of Information Management 23.

Calisir F., Gumussoy C. A., 2008, Internet banking versus other banking channels: Young consumers' view, International Journal of Information Management 28. 
Dąbrowski T. J., 2016, Ksztaltowanie reputacji banku komercyjnego. Podejście symboliczne i substancjalne, Oficyna Wydawnicza Szkoła Główna Handlowa w Warszawie, Warszawa.

Dziuba J., 2015, Finance and accounting for sustainable development: responsibility, ethic, financial stability, Publishing House of Wroclaw University of Economics, Wrocław.

International Organization for Standardization, 2014, Guidance on social responsibility, Discovering ISO 26000, Switzerland.

KNF, 2010, Ustugi bankowości elektronicznej dla klientów detalicznych. Charakterystyka i zagrożenia, Urząd Komisji Nadzoru Finansowego, Warszawa.

Komisja Europejska, Spoleczna odpowiedzialność przedsiębiorstw w UE, http://ec.europa.eu/ social/main.jsp?catId=331\&langId=pl, [accessed: 10.02.2017].

Korenik D., 2009, Odpowiedzialność banku komercyjnego. Próba syntezy, Difin, Warszawa.

Łukasiewicz-Kamińska A., 2011, Społeczna odpowiedzialność przedsiębiorstwa finansowego, Difin, Warszawa.

Milic-Czerniak R., 2012, Etyka $w$ działalności banków, miesięcznik finansowy BANK, Warszawa.

Pluskota P., 2003, Wspótczesne kanały dystrybucji produktów bankowych, Wydawnictwo Naukowe Uniwersytetu Szczecińskiego, Uniwersytet Szczeciński, Szczecin.

Polasik M., 2008, Bankowość elektroniczna, Istota-Stan-Perspektywy, CeDeWu, Warszawa.

Talukder M., Quazi A., Sathye M., 2014, Mobile Phone Banking Usage Behaviour: An Australian Perspective, Australasian Accounting, Business and Finance Journal, vol. 8, iss. 4.

Zalewska-Bochenko A., 2013, Bankowość telefoniczna i jej wplyw na rozwój bankowości elektronicznej [w:] Studia Ekonomiczne, nr 173 Innowacje w bankowości i finansach. T. 1, Uniwersytet Ekonomiczny w Katowicach.

\section{ETYCZNE ASPEKTY KOMUNIKACJI Z KLIENTEM W BANKOWOŚCI TELEFONICZNEJ}

\section{Streszczenie}

W obecnych czasach rozwój technologii umożliwia komunikację za pośrednictwem nowych kanałów. Internet oraz telefony komórkowe stały się głównym sposobem komunikacji. Banki i inne instytucje finansowe wykorzystują nowe formy komunikacji w celu utrzymania stałej relacji z klientami. Większość z tych form wspiera nie tylko działalność banków, ale także ułatwia klientom korzystanie z produktów i usług. Jedną z najbardziej popularnych form komunikacji z klientami stały się rozmowy telefoniczne. Jednocześnie obserwuje się rozwój koncepcji społecznej odpowiedzialności biznesu, która wyznacza etyczne zasady w biznesie. Niniejsza praca odnosi się do zagadnień konsumenckich. Omawia się etyczne aspekty, takie jak relacje z klientami, uczciwa i przejrzysta polityki marketingowa, edukacja rynku, rzetelna informacja na temat produktów i usług oraz ich wpływ na zdrowie i bezpieczeństwo klientów. Głównym celem pracy jest analiza czy bankowość telefoniczna jest postrzegana, jako etyczny sposób komunikacji z klientami. Artykuł analizuje etyczne aspekty bankowości telefonicznej, a także prezentuje wyniki empiryczne na podstawie badań przeprowadzonych wśród klientów.

Słowa kluczowe: bankowość telefoniczna, usługi finansowe, etyka biznesu, społeczna odpowiedzialność biznesu. 